\title{
ALAM DIGITAL MUHAMMADIYAH DAKWAH ISLAM WASHATIYAH BERKEMAJUAN
}

\author{
David Krisna Alka
}

\begin{abstract}
Abstrak
Belum ada kajian serius tentang gerakan digital Muhammadiyah. Tulisan ini bisa menjadi pembuka untuk mengkaji alam digital dakwah Muhammadiyah dalam konteks keindonesiaan dan kebangsaan. Beberapa pertanyaan dan kegelisahan muncul. Gerakan dakwah digital seperti apa yang akan dipersembahkan Muhammadiyah untuk bangsa ini. Muhammadiyah dikenal sebagai gerakan organisasi keagamaan yang modern, tetapi perangkat gerakan dakwahnya sudah modern atau belum, masih bimbang. Selain itu, alam digital dekat dengan alam pikir generasi baru Muhammadiyah. Menjadi tantangan generasi muda Muhammadiyah dan influencer-nya untuk memelihara dan menyebarkan prinsip Islam Wasathiyah. Generasi muda Muhammadiyah bergerak di bawah tenda besar Islam Wasathiyah dan gerakannya dibingkai dengan gerakan dakwah yang kekinian, kreatif dan inovatif. Dakwah digital Islam Wasathiyat perlu diperkuat di seluruh lini, dari pusat sampai cabang dan ranting.
\end{abstract}

Kata kunci: Muhammadiyah, Digital, Islam Wasathiyah, Kaum Muda

Sudah 107 tahun Persyarikatan Muhammadiyah menjadi tulang punggung roda kehidupan republik ini. Tentu tak perlu lagi dipaparkan atau diulangulang hal-hal apa saja yang telah dilakukan dan dikorbankan Muhammadiyah, aktornya maupun persyarikatannya. Pastinya, yang belum dipersembahkan 
Muhammadiyah kini adalah gerakan amal usaha digitalnya bagi kemajuan Indonesia. Sebelum bentuk gerakan digital apa yang akan dipersembahkan Muhammadiyah untuk bangsa ini, kita tengok dulu sejauh mana alam digital Muhammadiyah kini? Sedang menuju maju atau tertinggal jauh? Sebagai gerakan organisasi keagamaan yang modern biasanya sudah otomatis modern juga perangkat gerakannya. Tapi apa iya begitu?

\section{Gerakan Digital Seperti Apa?}

Saat ini gerakan dakwah persyarikatan dan amal usaha dengan berbagai macam rupanya mau tak mau harus melakukan gerakan digital. Semua organsisasi turunan dan amal usaha Muhammadiyah terpaksa, kalau tidak mau dikatakan dipaksa, bergerak ke alam digital. Bahkan, gerakan dakwah Muhammadiyah untuk umat pun kini mesti masuk ke alam digital. Tentu dengan panduan persyarikatan, terpimpin dan tidak tercerai berai. Era kini, dakwah dengan menggunakan platform media sosial banyak digunakan dan disukai. Karena daya tarik produk media digital memiliki keunikan, cepat sampai (nilai menghadirkan informasi terkini). Tak hanya berupa tulisan, ada gambar, gambar bergerak, dan video, yang berwarna disertai inovasi-inovasi grafis dari para kreator digital.

Globalisasi mencakup penyebaran cepat bahan-bahan dan produk, ide, gambar, aliran modal, dan orang-orang melintasi ruang dan perbatasan (nasional atau lainnya) yang sebelumnya jauh lebih sulit atau bahkan tidak terhubung sama sekali. Namun, globalisasi mesti menuntut pandangan pluralistik dan lintas budaya. Karenanya produksi media selalu berkembang. Apalagi dunia internet menjadi faktor utama masyarakat dunia nyata menjadi "demam" bentuk-bentuk inovasi platform digital.

Apalagi perangkat kekinian seperti smartphone dapat memuat segala bentuk aplikasi platform digital yang langsung terkoneksi dengan internet. Alhasil, realitas umat mau tak mau seolah berpindah dari dunia nyata ke dunia maya. Para tokoh umat, terpaksa kalau tidak dipaksa menjadi aktor infleuncer yang dapat mempengaruhi umat di alam digital. Karena itu, dalam konteks Muhammadiyah, guru besar sosiologi dan Ketua Umum Muhammadiyah, Haedar Nashir, menghimbau untuk menyusun fikih bermedia sosial dalam satu rangkaian fikih informasi dengan menampilkan etika publik dan etika relasi sosial baru berbasis etika Al-Hujarat. 
Haedar Nashir (2019) meminta Majelis Tarjih untuk menghadirkan dakwah dan tajdid di era media sosial dan revolusi 4.0, pedoman keagamaan atau keislaman untuk "hidup beradab di era medsos dan era 4.0. Dunia modern saat ini baik di tingkat global maupun nasional dan lokal antara lain memiliki kecenderungan "mengeras" (radikal, ekstrem) sebagai respons atau terkait dengan situasi kehidupan yang sarat antagonistik dalam berbagai aspek kehidupan.

Alam digital dekat dengan alam pikir generasi baru Muhammadiyah. Hendaknya pedoman keagamaan atau keislaman untuk hidup beradab di era medsos itu menjadi kekuatan teguh dalam bingkai rahmatan lil'alamin. Soalnya, beberapa hasil penelitian di bawah ini tentang intoleransi di kalangan generasi muda menjadi pekerjaan besar Muhammadiyah untuk dakwah digitalnya itu.

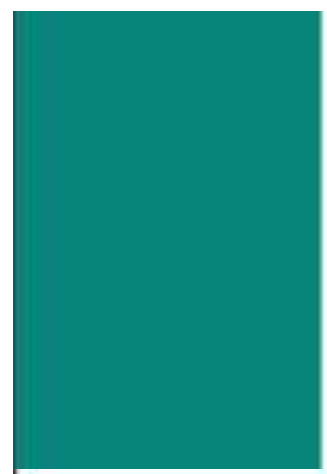

\section{PROBLEM INTOLERANSI KALANGAN GENERASI MUDA (1)}
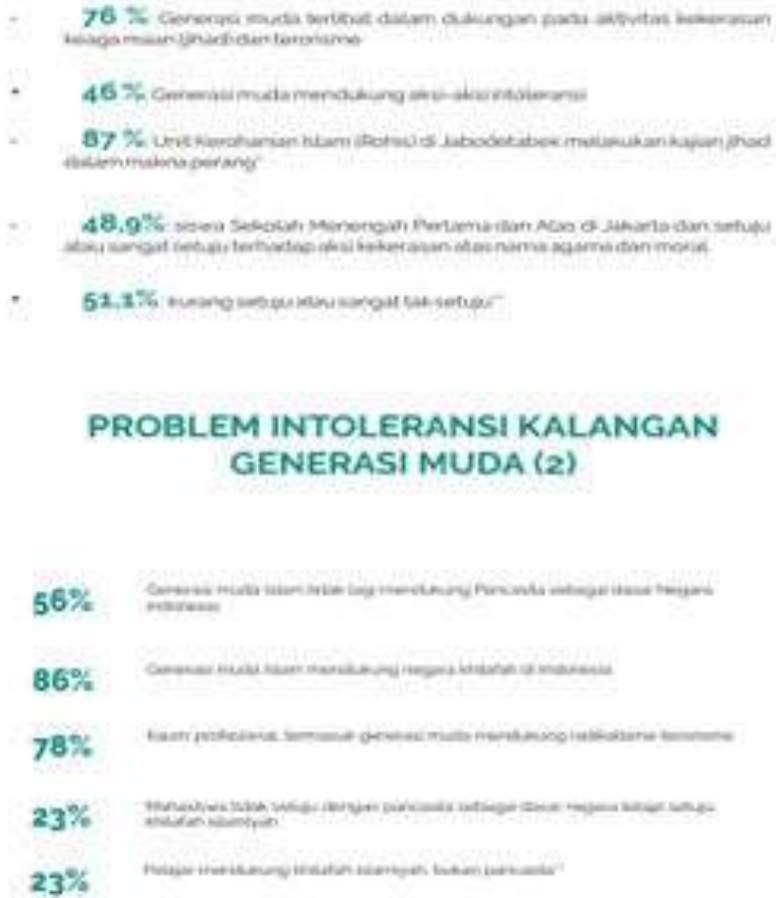


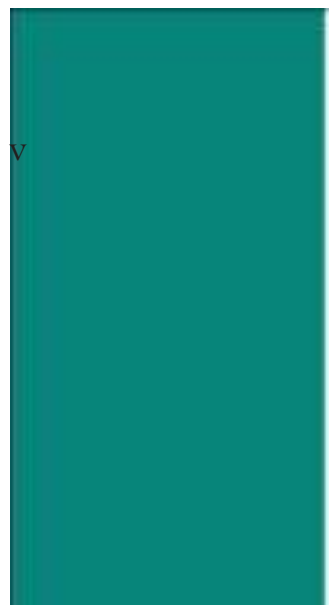

PROBLEM INTOLERANSI KALANGAN

GENERASI MUDA (3)

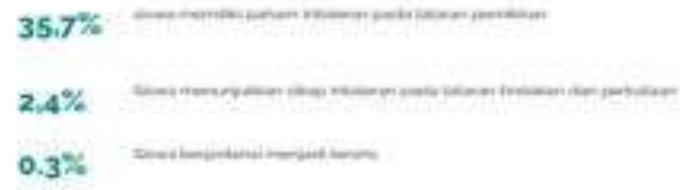

Mengamati problem intoleransi kalangan generasi muda di atas, perlu ramuan baru bagi gerakan dakwah digital Muhammadiyah sebagai upaya menguatkan nalar dan laku toleransi generasi baru Muhammadiyah. Lalu bagaimana caranya?

\section{Kegelisahan Lama}

Ahmad Fuad Fanani (2018: 87) jauh hari sudah mewanta-wanti, hidup di era menguatnya konservatisme bukanlah hal yang mudah. Bagi orang yang mempunyai pemikiran yang liberal-progresif dan getol memperjuangkan isu-isu keseteraan gender, demokrasi, perlunya reinterpretasi al-Qur'an, kebebasan berpikir, menghargai non Muslim dan kaum minoritas, serta pluralisme, sering dikafirkan, dimurtadkan, dan dianggap musuh Islam yang berasal dari dalam. Mereka dianggap bukan memperjuangkan Islam, tetapi malah merugikan Islam dan menguntungkan agama lainnya. Pada halaman berikutnya Ahmad Fuad Fanani, dengan mengutip Zainun Kamal, mengatakan, fenomena yang terjadi di Muhammadiyah sering berbalikan dengan zaman dulu. Jika dulu orang Muhammadiyah sering dikafirkan orang, sekarang justru orang Muhammadiyah-lah yang berbalik mengkafirkan orang.

Dari sejarah KH. Ahmad Dahlan, ketika awal-awal melakukan dakwah dan mendirikan Muhammadiyah, beliau kerap kali dikafirkan orang. Misalnya, ketika beliau berusaha meluruskan arah kiblat di Masjid Kauman, yang sebagian ulama dulu waktu itu dianggap mengada-ada dan merusak akidah 
umat. Begitu pula ketika beliau menyerukan khutbah dengan memakai bahasa Indonesia dan lain sebagainya.

Lain lagi dengan ceritanya Azyumardi Azra (2007). Suatu ketika saat berbicara dan berdialog dalam pengajian Ranting PP Muhammadiyah di kampus Universitas Muhammadiyah Yogyakarta, Azra menemukan banyak kegelisahan, kekhawatiran dan kecemasan peserta pengajian yang merupakan kalangan Pimpinan Muhammadiyah pada tingkat Nasional, wilayah/provinsi (PWM), dan organisasi otonom (ortom).

Sebagian kegelisahan dan kekhawatiran itu bukan hal yang baru; sudah lama menjadi wacana dan perdebatan di lingkungan Muhammadiyah sendiri, dan juga menjadi sorotan kalangan pengamat luar. Sebagian kegelisahan itu agaknya sudah ada sepanjang usia Muhammadiyah. Ya, kegelisahan dan kegundahan tersebut sampai sekarang memang belum juga usai. Hingga kini kegelisahan yang sama masih ada. Kegelisahan seperti apakah itu? Ya, fenomena radikalisme serta bibit intoleransi yang menyeret kalangan anak muda Muhammadiyah. Apalagi saat ini, ruang politik yang terang benderang memainkan isu agama memiliki potensi untuk makin memudarkan prinsip Washatiyah ke jantung gerakan generasi muda Muhammadiyah. Seperti apa prinsip Islam Washatiyah ini?

\section{Dakwah Digital Islam Washatiyah}

Menurut Grand Sheikh Al-Azhar, Mesir, Ahmad Mohamad ath-Tayeb (2018), Islam Washatiyah merupakan konsep dasar Islam yang tidak diragukan lagi. Wasat adalah adil, sehingga umat Islam sebagai umat Wasat adalah umat yang adil. Sudah banyak literatur mengenai Wasat dengan keadilan. Adil didefinisikan sebagai menempatkan sesuatu sesuai porsinya, tidak berlebihan, tidak ke kutub ekstrem, baik kanan maupun kiri.

Konsep Wasatiyyat adalah konsep yang selalu diperbaharui, sebuah konsep agama Islam yang berjalan di jalan tengah. Allah sudah mengatakan umat Islam umat Wasatiyyat dalam Al-Qur'an. Agar umat Islam jadi saksi, Wasatiyyat adil. Tak berbeda dengan pandangan Ketua umum PP Muhammadiyah Haedar Nashir (2018). Menurutnya, Islam Wasathiyah yang dikembangkan harus dibarengi dengan spirit Islam yang Berkemajuan. Sekadar menjadi umat yang moderat tidak cukup, umat Islam harus unggul dan bisa mengambil momentum untuk memenangkan perlombaan peradaban. 
Umat Wasathiyah sebenarnya merupakan karakter umum muslim baik di Indonesia maupun dunia, namun artikulasinya sering beragam dan tidak dimonopoli oleh satu kelompok. Selain itu, umat tengahan juga harus dinamis dan memiliki keunggulan sebagaiamana karakter "khaira ummah" untuk menjalankan misi dakwah "al amr bi al-ma'ruf", "wa nahy 'an al-munkar", dan "wa tu'minuna billah” (QS Ali Imran: 110).

Dalam konteks kekinian, menurut Haedar, sungguh penting dan relevan kehadiran Islam Indonesia dan Islam dunia yang berkemajuan. Umat Islam yang moderat harus tampil sebagai umat berkemajuan, bukan sebagai golongan yang besar sebatas jumlah. Apalah artinya besar secara kuantitas tetapi kalah dalam kualitas. Kata pepatah Arab, faaqid asy-syaiy la yu'thi, bahwa orang atau kelompok yang tidak memiliki sesuatu tidak mungkin dapat memberi sesuatu kepada pihak lain.

Jadi tantangan generasi muda Muhammadiyah dalam memelihara dan menyebarkan prinsip Islam Wasathiyah kepada generasi muda Muhammadiyah. Generasi muda Muhammadiyah saat ini, meminjam pandangan Masdar Hilmy (2012), pendasaran dalam beragamanya sama dengan masyarakat secara umum, lebih banyak dilakukan melalui faktor-faktor lingkungan sosiologis yang memiliki daya koreksi terhadap pengambilan keputusan kalangan mayoritas dalam mengadopsi sikap keagamaan mereka. Artinya, kecenderungan sikap beragama mereka lebih banyak ditentukan oleh pertimbangan pragmatissosiologis belaka, bukan argumentasi atau narasi teologis yang mendalam.

Masyarakat mudah ikut pada arus yang sedang berkembang tanpa mampu mengambil jalan tengah dan atau wacana kritis. Mereka selalu terbawa oleh angin perubahan yang terjadi di lingkungan sekitar. Mereka seakan tidak memiliki kemerdekaan berpikir dan bertindak atas apa yang dikerjakan. Hal tersebut tidak menjadi masalah jika ulama atau para tokoh muda Muhammadiyah di pusat dan daerah sebagai penganjur moderatisme menjadi panutan, bersama masyarakat dan generasi muda mendorong kehidupan bermoral dan beradab. Namun, jika yang memengaruhi lingkungan sosial adalah ulama dan pimpinan yang mempunyai pandangan bahwa Pancasila dan UUD 1945 adalah thogut (sesembahan, berhala, tuhan), pasti menimbulkan masalah. Masyarakat pun akan mudah menjadi martil aksi kekerasan atas nama agama.

Tokoh-tokoh muda Muhammadiyah segera dan saatnya kini menyapa umat di forum-forum dakwah, forum akademis di semua universitas Muhammadiyah dan pengajian di semua amal usaha Muhammadiyah menyapa dan menanamkan 
Islam Washatiyah yang berkemajuan. Generasi muda Muhammadiyah perlu dididik agar mereka mempunyai kesadaran kritis. Tidak boleh selamanya menjadi "pengikut" tanpa adanya autokritik yang berdasarkan nalar sehat. Kehidupan keagamaan akan sehat saat masyarakat tidak begitu saja menerima ajaran agama yang dianutnya (taklid buta).

Selain itu, sesuai konteks judul tulisan ini, generasi muda Muhammadiyah lintas Ortom perlu bersinergi melakukan aksi bersama dakwah digital Islam Washatiyan dan Islam berkemajuan. Kader muda Muhammadiyah perlu sadar bahwa tantangan saat ini tidak semakin mudah. Sebagai penjaga narasi keislaman Indonesia, kaum muda Muhammadiyah perlu memikirkan formula yang tepat untuk tetap mengukuhkan dakwah digital Islam Washatiyah yang berkemajuan.

\section{Influencer Islam Washatiyah}

Influencer Muhammadiyah, siapa saja mereka? Siapa tokoh-tokoh muda Muhammadiyah yang dapat disebut sebagai influencer di Indonesia? Benarkah mereka orang-orang yang punya followers atau audience yang cukup banyak di media sosial dan punya pengaruh yang kuat terhadap followers mereka? Lantas, sejauh mana mereka menyiarkan prinsip Wasatiyyat Islam, seperti tawassuth, tawazun, i'tidal, tasamuh, musawah (egaliter), syura, islah, aulawiyah (mendahulukan yang prioritas), tathawwur wa Ibtikar (dinamis dan inovatif), dan tahadhdhur (berkeadaban)?

Jawaban dari pertanyaan itu perlu ditemukan dan dipetakan dalam diri kaum muda Muhammadiyah yang berserak di berbagai ortomnya. Soal prinsip Wasatiyyat Islam itu terdapat dalam buku usulan Indonesia untuk Konsultasi Tingkat Tinggi Ulama dan Cendekiawan Muslim Dunia Tentang Wasatiyyat Islam (Bogor, 1-3 Mei 2018) yang digagas Prof. Din Syamsuddin. Prinsipprinsip Wasatiyyat Islam itu mengkristal dalam perilaku muslim baik individual maupun kolektif dalam berbagai aspek kehidupan. Namun tetap yang menjadi pertanyaan siapa influencer kalangan Muhammadiyah-istilah anak sekarang-yang bisa bikin viral.

Tengoklah data beberapa hasil penelitian tentang intoleransi di kalangan generasi muda di atas, sejauhmana sudah sampai dakwah digital Islam moderat Muhammadiyah itu? Selain itu, hasil penelitian pada 2017 menunjukkan Generasi Z memiliki opini intoleran dan radikal yang bisa menjadi aksi intoleran 
dan radikal. Radikalisasi salah satunya terjadi di kampus. Kalangan intelektual sengaja dibidik. Kecenderungan Generasi Z yang intoleran membuka jalan bagi mereka untuk permisif pula terhadap infiltrasi ide-ide radikal. Tidak heran jika bom bunuh diri yang terjadi di Surabaya, Jawa Timur, pada 2018 melibatkan anak berusia 7 tahun (Lihat: Generasi Z di Bawah Ancaman Intoleransi, Harian Kompas, 21 November 2019).

Walhasil tugas berat dan pekerjaan besar bagi influencer Muhammadiyah untuk dakwah digitalnya itu. Selain juga perlu bagi ulama-ulama muda Muhammadiyah hadir di tengah pengajian dan kehidupan masyarakat umum, dan mengetuk pintu kehidupan sosial dan politik yang beradab, moderat dan berkemajuan.

Untuk itu perlu kesadaran tinggi bahwa tantangan keberagamaan hari ini tidak kalah pelik dibandingkan dengan urusan politik kekuasaan semata. Kaum muda Muhammadiyah perlu selalu berlindung di bawah tenda besar Islam Washatiyah yang berkemajuan. Karena itu, dakwah digital Islam Moderat perlu diperkuat di seluruh lini, dari pusat sampai cabang dan ranting. 